\title{
Effect of Host Plant, Aphid Species, and Virus Infection Status on Transmission of Sweetpotato feathery mottle virus
}

E. N. Wosula and C. A. Clark, Department of Plant Pathology and Crop Physiology, and J. A. Davis, Department of Entomology, Louisiana State University Agricultural Center, Baton Rouge 70803

\begin{abstract}
Wosula, E. N., Clark, C. A., and Davis, J. A. 2012. Effect of host plant, aphid species, and virus infection status on transmission of Sweetpotato feathery mottle virus. Plant Dis. 96:1331-1336.

Sweetpotato feathery mottle virus (SPFMV) is a nonpersistently transmitted virus known to infect sweetpotato (Ipomoea batatas) and wild morning glory plants. SPFMV is vectored by various aphid species, among them the green peach aphid, Myzus persicae, and the cotton aphid, Aphis gossypii. Our objective was to determine whether differences in acquisition hosts (sweetpotato and morning glory), aphid species (M. persicae and A. gossypii), and infection status (single versus mixed infection) influenced transmission of SPFMV. SPFMV transmission from $I$. hederacea with a natural mixed infection by $A$. gossypii (39\%) was significantly greater than in other host-virus combinations. Successful transmissions by A. gossypii were signifi-

cantly greater compared with $M$. persicae in all host-virus combinations. Virus titers in source leaves were significantly greater in singleand mixed-infected $I$. hederacea and single-infected I. cordatotriloba compared with other host-virus combinations. There was a significant positive correlation between virus titer and transmission by both aphid species. These results suggest that, under controlled conditions, SPFMV is more readily transmitted from infected morning glory plants than from sweetpotato. Additionally, mixed-infected plants are better virus sources for transmission than single-infected, and $A$. gossypii is a more efficient vector than $M$. persicae under laboratory conditions.
\end{abstract}

Sweetpotato (Ipomoea batatas L.) is the seventh most important food crop in the world, with an annual production of approximately 130 million tons, ranking third among root and tuber crops worldwide (13). It is increasing in demand in the United States because it is increasingly regarded as uniquely nutritious food, with more processed products becoming available. Sweetpotato is an important carbohydrate source, especially in Africa, where it provides household food security, because it persists well in the soil as a famine reserve crop and performs well in marginal soils $(3,10)$. Sweetpotato is vegetatively propagated and is prone to accumulate viruses which cause cultivar yield decline and reduce storage root quality $(7,8)$. The most common sweetpotato viruses in the United States are members of the family Potyviridae and the genus Potyvirus: Sweet potato feathery mottle virus (SPFMV), Sweetpotato virus G (SPVG), and Sweetpotato virus 2 (SPV2, synonym $=$ Ipomoea vein mosaic virus) $(5,9,33)$. Sweetpotato Potyvirus spp. are restricted primarily to the family Convolvulaceae, transmitted by aphids, and occur commonly as mixed infections in the field $(3,24,35)$.

SPFMV is the most common sweetpotato virus and occurs in all sweetpotato-growing areas, including the United States (9). Four strains were originally differentiated: russet crack (RC), common (C), ordinary $(\mathrm{O})$, and East African (EA) $(17,21)$. The RC and C strains are widely distributed, whereas EA seems to be most common in Africa, though it has also been reported in Peru, Spain, and Easter Island $(14,21,29,40)$. However, the C strain was recently separated into a distinct species, Sweet potato virus $C$ (SPVC), due to its sequence divergence from the other three strains (39). Single infections of SPFMV or mixed infections with SPVG and SPV2 in

Corresponding author: C. A. Clark, E-mail: CClark@agcenter.lsu.edu

This article was approved for publication by the Director of the Louisiana Agricultural Experiment Station as manuscript number 2011-240-6496.

Accepted for publication 9 April 2012.

http://dx.doi.org/10.1094/PDIS-11-11-0934-RE

(C) 2012 The American Phytopathological Society
'Beauregard' sweetpotato usually show mild chlorotic spotting and veinal chlorosis or no symptoms, and cause little or no yield loss $(10,20)$. However, naturally infected sweetpotato plants (i.e., grown in the field for several years) which test positive for these three Potyvirus spp. and negative for other known sweetpotato viruses, may display distinct symptoms accompanied with yield reduction $(7,10)$, possibly indicating the presence of other unknown viruses.

Mixed virus infections can positively or negatively impact transmission rates and alter patterns of virus spread (30). Mixed infections could be better sources of inoculum for some viruses whereas, for others, transmission rates are greater from single infections (30). In Louisiana, after one generation in the field, plants are commonly infected with SPFMV but, by the fourth generation, plants usually test positive for SPFMV (100\%), SPVG (50 to $70 \%$ ), and SPV2 (25 to 30\%) (10). Because SPVC was not recognized as a distinct species until this year, data are not available for its occurrence.

Experimental host range studies suggest that other wild virus hosts are potential sources of inoculum, (9) mainly morning glory plants in the genus Ipomoea, family Convolvulaceae $(22,38)$. In Louisiana, the morning glory species I. cordatotriloba Dennst. (synonym I. trichocarpa Ell.) and I. hederacea Jacq. are common in and around sweetpotato fields, and I. hederifolia L., I. lacunosa L., and I. wrightii (Wall.) are also known wild hosts of SPFMV (6).

SPFMV is transmitted by several aphid species (35) in a nonpersistent manner $(17,18)$. Aphid vectors acquire and transmit $\mathrm{Po}$ tyvirus spp. to susceptible plants without necessarily colonizing the infected plants due to their sap sampling/probing feeding habit (27). These aphids acquire the virus in as short as 3 to $35 \mathrm{~s}$ (23), and retain the virus for a short period, normally less than $2 \mathrm{~h}$ (25). Efficient vectors of SPFMV are the aphid species Myzus persicae and Aphis gossypii $(3,35)$. M. persicae occasionally colonizes sweetpotato in Louisiana; while A. gossypii has been found on $I$. hederacea (C. A. Clark, unpublished data).

Potyvirus spp. are detected in sweetpotato using various combined methods. Because they exist in very low titers in sweetpotato (19), graft indexing on I. setosa is traditionally used to detect its presence and subsequent testing using other techniques. The most widely used serological method (5) is a membrane immune-bind- 
ing assay known as nitrocellulose membrane enzyme-linked immunosorbent assay (NCM-ELISA). Reverse-transcription polymerase chain reaction (RT-PCR) and real-time RT-PCR are also used for detection and quantification $(5,19)$.

The aim of this study was to determine the transmission efficiency of SPFMV-RC, the most prevalent Potyvirus strain in Louisiana, from potential sources which may occur in the field. We tested transmission efficiency from the predominant Louisiana sweetpotato cultivars, Beauregard and 'Evangeline'; the two most common morning glory plants in or near sweetpotato fields, $I$. hederacea and I. cordatotriloba; and compared single SPFMV infections with representative natural mixed infections using the aphid vectors $M$. persicae and $A$. gossypii.

\section{Materials and Methods}

Host plants. I. nil 'Scarlet O'Hara' (SOH) was used as the test plant in all studies. The following Ipomoea spp. were used as SPFMV acquisition sources: Beauregard and Evangeline sweetpotato, I. cordatotriloba (cotton morning glory), and I. hederacea (ivy-leaf morning glory). Sweetpotato plants were derived from virus-tested mericlones maintained by nodal propagation in tissue culture at the LSU AgCenter Department of Plant Pathology and Crop Physiology. I. cordatotriloba and I. hederacea were established from seed harvested from single plants that were grown in the greenhouse. All plants were grown in the greenhouse under wide temperature $\left(10\right.$ to $32^{\circ} \mathrm{C}$ ) and humidity (21 to $98 \%$ ) ranges, in 10 -cm-diameter clay pots containing autoclaved soil mix consisting of 1 part river silt, 1 part sand, 1 part Jiffy-Mix Plus (Jiffy Products of America Inc.), and Osmocote 14-14-14 (ScottsSierra Horticultural Products Company) at $3.5 \mathrm{~g} / \mathrm{pot}$. Plants were not sprayed with insecticide. Establishment of sweetpotato plants from virus-tested mericlones and morning glory plants from seed ensured they were virus free before being used in studies.

Virus inoculum. Two inoculum sources were used in our transmission studies: plants infected with the RC strain of SPFMV (SPFMV-RC, isolate 95-2) maintained in $\mathrm{SOH}$ in the greenhouse by repeated mechanical inoculation, and a naturally mixed-infected Beauregard sweetpotato (B 14, G-7) that was grown in fields in North Carolina for 7 years and provided by G. C. Yencho (Department of Horticultural Sciences, North Carolina State University, Raleigh). B 14, G-7 was tested using NCM-ELISA after grafting on I. setosa, RT-PCR, and real-time RT-PCR and found to be infected with SPFMV, SPVG, and SPV2 but tested negative for Sweet potato mild mottle virus, Sweet potato latent virus, Sweet potato chlorotic fleck virus, Sweet potato mild speckling virus, Sweet potato leaf curl virus, Sweet potato chlorotic stunt virus (SPCSV), Sweet potato collusive virus, and Cucumber mosaic virus (CMV). However, the possibility that it was infected by viruses not yet recognized in sweetpotato cannot be eliminated.

Aphid colonies. A. gossypii was collected from cotton at the LSU AgCenter Macon Ridge Research Station, Winnsboro, LA in 2006, while $M$. persicae was collected from an unknown host in 2004. Aphid colonies were established from single apterae and maintained under laboratory conditions in screened cages at room temperature $\left(20\right.$ to $\left.22^{\circ} \mathrm{C}\right)$ and a photoperiod of $16 \mathrm{~h}$ of light and $8 \mathrm{~h}$ of darkness. A. gossypii was reared on 'Stoneville 474' cotton plants (Gossypium spp.), while M. persicae was reared on 'Tendergreen' mustard plants (Brassica cretica L.), neither of which has been described as a host for sweetpotato viruses. Plants were grown in the greenhouse under wide temperature $\left(10\right.$ to $\left.32^{\circ} \mathrm{C}\right)$ and humidity (21 to $98 \%$ ) ranges, fertilized on a weekly basis with NPK 20-20-20 (Scotts-Sierra Horticultural Products Company), and kept free of insecticides. A cohort of 5 to 10 aphids was placed on fresh plants using a paint brush to establish new colonies every 2 to 3 weeks.

NCM-ELISA assays. Leaf tissue was collected from symptomatic plants and assayed by NCM-ELISA (10) using antisera produced to the SPFMV-RC provided by J. W. Moyer (North Carolina State University, Raleigh), or antisera to isolates from Louisiana of SPVG and SPV2 provided by S. Fuentes (International Potato
Center, Lima, Peru). A small piece (approximately $1 \mathrm{~cm}^{2}$ ) was collected from a lower, middle, and upper leaf of each plant, combined, placed in a "Universal" extraction bag (article number 430100; BIOREBA), and homogenized using a HOMEX6 homogenizer (BIOREBA) in $8 \mathrm{ml}$ of Tris-buffered saline (TBS; 0.02 $\mathrm{M}$ Tris base and $0.50 \mathrm{M} \mathrm{NaCl}), \mathrm{pH} 7.5$, containing $0.2 \%$ sodium sulfite $\left(\mathrm{Na}_{2} \mathrm{SO}_{3}\right)$. The extracted tissue $(2 \mathrm{ml})$ was transferred to a 2$\mathrm{ml}$ microfuge tube and allowed to stand for 30 to $45 \mathrm{~min}$ at room temperature. The clarified sap extract $(50 \mu \mathrm{l})$ was blotted onto a TBS buffer-saturated nitrocellulose membrane and air dried for 20 to $30 \mathrm{~min}$. All the incubations and washings were done at room temperature in a shaker with gentle agitation (50 rpm for incubations and $100 \mathrm{rpm}$ for washings) using reagents and procedures according to Clark et al. (10). The first antibody (polyclonal specific to SPFMV, SPVG, or SPV2) was cross absorbed in healthy $I$. setosa extract ( $1 \mathrm{~g}$ of tissue homogenized in $25 \mathrm{ml}$ of TBS containing sodium sulfite at $2 \mathrm{~g} /$ liter, Carnation skim milk [Nestlé USA, Inc.] at $20 \mathrm{~g} /$ liter, and sodium azide at $0.2 \mathrm{~g} /$ liter; $\mathrm{pH}$ 7.5) for 45 min at $37^{\circ} \mathrm{C}$ and was then added to the membranes and incubated 1 h. Positive reactions were determined by visual assessment, and a purple color reaction was recorded as positive.

Establishment of virus acquisition and test plants. Virustested Beauregard and Evangeline sweetpotato were graft inoculated with SPFMV-RC isolate 95-2 using scions from infected $\mathrm{SOH}$ plants. The isolate was maintained in $\mathrm{SOH}$ by serial mechanical inoculations and routinely tested for SPFMV by NCM-ELISA. Two wedge grafts were made per plant by inserting a single-node vine segment from the source plant into a slit in the stock plant. Only those on which scions survived for 3 weeks were used. Because titers in sweetpotato are often too low for detection by ELISA $(5,20)$, plants were assayed for successful inoculation by grafting onto the standard virus indicator plant, Brazilian morning glory (I. setosa), and only those that produced typical SPFMV symptoms were used for study. I. hederacea and I. cordatotriloba seedlings were mechanically inoculated with SPFMV-RC, isolate 95-2. Carborundum-dusted cotyledons of plants were rubbed approximately 5 to 7 days after planting with sap extracts from I. nil plants in which the isolate was maintained. Sap was obtained by grinding small leaf portions expressing symptoms in $1 \mathrm{ml}$ of inoculation buffer ( $0.05 \mathrm{M}$ sodium phosphate with $0.01 \mathrm{M}$ diethyldithiocarbamic acid) using a sterilized mortar and pestle. Plants were rinsed with distilled water after inoculation. Only those expressing typical SPFMV symptoms 3 weeks after inoculation were used for aphid transmission studies. For plants infected with the "natural" mix of viruses, vine cuttings were obtained from B14, G-7 and established in 15-cm-diameter clay pots. Scions from the naturally mixed-infected plants were then used to graft inoculate 6-week-old plants of I. hederacea, I. cordatotriloba, and sweetpotato Evangeline. In the case of Evangeline, plants with scions that survived for 3 weeks were assayed on the indicator plant I. setosa to confirm successful SPFMV inoculation. Only plants that indexed as positive for SPFMV on I. setosa were used for aphid transmission studies. NCM-ELISA assays confirmed that mixed-infected source plants had SPFMV and SPVG.

Transmission experiments with $A$. gossypii and $M$. persicae. $\mathrm{SOH}$ plants were used as test plants at the cotyledonary stage, approximately 5 to 7 days after sowing. The following treatments were carried out, each on 20 test plants per experiment that were repeated five times. Virus source plants were I. hederacea, I. cordatotriloba, and Beauregard and Evangeline sweetpotato for both single infection with SPFMV-RC isolate 95-2 and the naturally mixed infection.

Adult apterae (non-winged) aphids of M. persicae and A. gossypii were removed using a camel's hair brush from respective colonies, placed in separate petri dishes lined with moist filter paper, and fasted for $2 \mathrm{~h}$. Fresh leaves expressing the most distinct symptoms of SPFMV (except for single-infected Beauregard and Evangeline, on which all leaves were asymptomatic) were obtained from respective source plants 3 weeks after mechanical inoculation or 5 to 6 weeks after graft inoculation. Leaves corresponded to 
those that have high or most consistent titer (E. N. Wosula, unpublished). A single leaf was placed on a moist filter paper under a dissecting light microscope. One adult aptera was transferred from the petri dish using a camel's hair brush to the source leaf. Each aphid was monitored until it probed the leaf, as indicated by its assuming a resting position, and then allowed an acquisition access period (AAP) of $3 \mathrm{~s}$ in preliminary tests and $30 \mathrm{~s}$ in subsequent tests, after which it was transferred to an individual test plant. In each experiment, the same source leaf was used for testing both $A$. gossypii and $M$. persicae and, in most experiments, singly and mixed-infected leaves were tested at the same time. Due to the number of transmissions involved, it was not possible to test all host species at the same time. The procedure was repeated for each of the eight acquisition source plants, 20 aphids per replicate, five replicates each ( $n=100$ for each acquisition source for each aphid). The individual source leaves used for acquisition were frozen in liquid nitrogen and then stored at $-70^{\circ} \mathrm{C}$ for subsequent determination of virus titer using real-time RT-PCR. Individual viruliferous aphids were allowed an inoculation access period of 2 $\mathrm{h}$, after which plants were sprayed with imidacloprid (Admire 2F; Bayer CropScience) at a rate of $0.9 \mathrm{~g}$ a.i./liter of water to kill the aphids. Plants were left in the laboratory overnight, and then transferred back to a greenhouse for symptom monitoring. Plants were monitored daily for 3 weeks and those expressing typical SPFMV symptoms were recorded. Infected plants with transmissions from mixed-infected sources were tested using NCM-ELISA to confirm the presence of SPFMV. Another transmission experiment was conducted with both aphid species using a 3-s AAP on I. hederacea and I. cordatotriloba single-infected and Beauregard single and mixed-infected. The two aphid species were allowed to probe the same individual leaf in each experiment but hosts and virus combinations were not necessarily tested at the same time due to time factors. Transmission efficiency of SPFMV was estimated based on number of plants exposed, and the number of those infected by maximum likelihood using a Microsoft Excel Add-In PooledInfRate, version 3.0 (2). Additional differences in pooled data for host plants, infection status, and aphid species were tested using GLM PROC GENMOD (SAS Software version 9.2).

Quantitative RT-PCR assays. The real-time RT-PCR assays were carried out according to procedures of Kokkinos and Clark (19). Frozen leaf tissue (approximately $70 \mathrm{mg}$ ) was ground to a fine powder in liquid nitrogen using a mortar and pestle, and total RNA was extracted using Qiagen's RNeasy Plant Mini Kit (Qiagen Inc.) according to the manufacturer's directions. RNA concentrations were determined using a Nanodrop spectrophotometer (Nanodrop Technologies). To eliminate residual DNA, total RNA samples were treated with DNase I (Invitrogen). Real-time RTPCR assays were performed in $25-\mu \mathrm{l}$ reaction volume mixtures containing $900 \mathrm{nM}$ each primer (forward and reverse); $200 \mathrm{nM}$ MGB TaqMan probe; $12.5 \mu \mathrm{l}$ of $2 \times$ Master mix; $0.63 \mu$ of RT enzyme mix $(40 \times)$, which contains MultiScribe Reverse Transcrip- tase and RNase Inhibitor respectively, of the TaqMan One-Step PCR Master Mix Reagents kit (Applied Biosystems); and $2.5 \mu \mathrm{l}$ of template RNA. The same protocol was followed for the endogenous control reactions, which enable normalization of variation between sample extracts, except for the substitution of the target virus primer/probe set with $2.5 \mu \mathrm{l}$ of the eukaryotic $18 \mathrm{~S}$ rRNA primer/probe mix (VIC/MGB Probe; Applied Biosystems). The following real-time RT-PCR thermal cycling conditions were used: $48^{\circ} \mathrm{C}$ for $30 \mathrm{~min}$ (cDNA synthesis), $95^{\circ} \mathrm{C}$ for $10 \mathrm{~min}$, followed by 40 cycles of denaturation at $95^{\circ} \mathrm{C}$ for $15 \mathrm{~s}$ and annealing and extension at $60^{\circ} \mathrm{C}$ for $1 \mathrm{~min}$. All real-time RT-PCR reactions were performed on an ABI PRISM 7000 Sequence Detection System using MicroAmp optical 96-well reaction plates that are sealed with optical adhesive covers (Applied Biosystems). To compensate for any errors due to pipetting differences, duplicates of each sample were performed on each plate, and their threshold cycle $(\mathrm{Ct})$ values were averaged during data analysis. A fivefold standard curve of six dilutions was developed using a positive control of SPFMV$\mathrm{RC}$, isolate 95-2 RNA extract from SOH to test for any inhibition of optimal PCR conditions. In addition, every plate contained duplicate wells with a no-template control, a negative control with RNA extracts from healthy $\mathrm{SOH}$, and a positive control used for standard curves. Virus RNA titers $(\mathrm{N})$ were normalized based on the mathematical formula $N=2-\Delta \mathrm{Ct}$, where $\Delta \mathrm{Ct}$ is the difference between the Cts of the target virus and endogenous control (18S RNA) obtained from their respective real-time amplification plots. The Ct threshold was set by manually adjusting the base line and the threshold according to ABI PRISM 7000 Sequence Detection System manual instructions, to assure that it is in the linear phase of amplification for abundant 18S rRNA (Applied Biosystems). Data were log transformed and analyzed using PROC GLM, PROC Means, and PROC Corr procedures (SAS Software version 9.2).

\section{Results}

Transmission experiments with A. gossypii and M. persicae. The only successful transmission from sweetpotato was with $A$. gossypii from mixed-infected Beauregard for both 3- and 30-s acquisitions (Tables 1 and 2). SPFMV-RC transmission from mixed- compared with single-infected sources within host plants was significantly greater in I. hederacea with A. gossypii but no significant differences were observed for other individual hosts (Table 1). M. persicae yielded no significant differences in transmission from mixed- compared with single-infected sources within host plant species. No successful transmission of SPFMV occurred with Evangeline as source from either mixed- or singleinfected or from single-infected Beauregard (Tables 1 and 2). The 3 -s probe yielded successful transmissions of SPFMV in some host-virus combinations by both aphid species, though at lower rates compared with the 30 -s probes (Tables 1 and 2 ). According to the NCM-ELISA results, all test plants whose virus sources were mixed-infected tested positive for SPFMV. All transmissions by $M$.

Table 1. Sweet potato feathery mottle virus (SPFMV) transmission from Ipomoea spp. from single and mixed infections by Aphis gossypii and Myzus persicae following $30-\mathrm{s}$ acquisition probes $^{\mathrm{a}}$

\begin{tabular}{|c|c|c|c|c|}
\hline \multirow[b]{3}{*}{ Acquisition source ${ }^{b}$} & \multicolumn{4}{|c|}{ Transmission $(\%)$} \\
\hline & \multicolumn{2}{|c|}{ A. gossypii } & \multicolumn{2}{|c|}{ M. persicae } \\
\hline & Mean & CI & Mean & CI \\
\hline Ipomoea batatas 'Beauregard' SPFMV-RC & 0 & NT & 0 & NT \\
\hline I. batatas Beauregard mixed & 7 & $3.1-13.3$ & 0 & NT \\
\hline I. batatas 'Evangeline' SPFMV-RC & 0 & NT & 0 & NT \\
\hline I. batatas Evangeline mixed & 0 & NT & 0 & NT \\
\hline I. cordatotriloba SPFMV-RC & 15 & $9.5-22.2$ & 9 & $4.9-15.3$ \\
\hline I. cordatotriloba mixed & 20 & $13.1-28.7$ & 8 & $3.8-14.6$ \\
\hline I. hederacea SPFMV-RC & 21 & $14.9-27.4$ & 10 & $6.5-16.1$ \\
\hline I. hederacea mixed & 39 & $29.8-48.8$ & 18 & $11.4-26.4$ \\
\hline Control & 0 & NT & 0 & NT \\
\hline
\end{tabular}

${ }^{a}$ Means within a column (acquisition sources) with same confidence interval $(\mathrm{CI})$ range are not significantly different $(P>0.05)$. NT $=$ no transmission occurred; therefore, no CIs can be calculated.

${ }^{\mathrm{b}} \mathrm{RC}=$ russet crack strain; $n=100$ for each acquisition source. 
persicae tested positive for SPFMV alone, whereas some transmissions by A. gossypii from all hosts tested positive for both SPFMV and SPVG and none tested positive for SPVG alone (Table 3). A. gossypii had a significantly greater transmission efficiency compared with $M$. persicae $\left(\chi^{2}=13.77, P=0.0002\right)$ when data were analyzed across all sources. When exposed simultaneously, I. hederacea was a better SPFMV source compared with other hosts $\left(\chi^{2}=\right.$ 20.66, $P \leq 0.0001)$, and mixed-infected leaves were better SPFMV sources than single-infected ones $\left(\chi^{2}=8.78, P \leq 0.0030\right)$.

SPFMV RNA titer in relation to aphid transmission. Quantification of SPFMV RNA titers in mixed and single infections revealed significant differences within some hosts. SPFMV titer was significantly greater in Beauregard mixed-infected than in single-infected plants, but I. cordatotriloba mixed-infected had a significantly lower titer than in single-infected. No significant differences between mixed- and single-infected were observed within other hosts. Virus titers were generally significantly greater, as was SPFMV transmission by A. gossypii and M. persicae, in the I. hederacea and I. cordatotriloba single-infected morning glory plants than in the sweetpotato Beauregard and Evangeline (Fig. 1). Correlation analysis revealed a significantly positive relationship between transmission and virus titer for both $A$. gossypii and $M$. persicae ( $r=0.74, P=0.0131$ and $r=0.82, P=0.0347$, respectively).

\section{Discussion}

Dramatic differences in transmission of SPFMV occurred from different source plants depending on both host species and infection status. Based on our results under laboratory conditions, both A. gossypii and $M$. persicae are more likely to acquire and transmit SPFMV from infected I. hederacea and I. cordatotriloba than from infected Beauregard or Evangeline sweetpotato. Significantly greater SPFMV titers occurred in morning glory plants compared with sweetpotato plants. We suggest that SPFMV replication in morning glory plants is more rapid compared with sweetpotato; hence, high titers occur that enable easier acquisition and transmission by aphids. Kennedy and Moyer (17) revealed a similar trend in which transmission of SPFMV was lower when aphids were allowed to probe sweetpotato leaves compared with I. setosa leaves from graft-inoculated plants. Other studies have also reported effect of host on virus accumulation (e.g., weedy hairy nightshade [Solanum sarrachoides], common in potato-growing regions, is a better source of both Potato virus Y [PVY] and Potato leafroll vi- rus; 1,4,34). Differences among hosts in transmission rates by aphids could be attributed to varying levels of virus titer in source leaves depending on their position on the plant, a phenomenon previously reported involving transmission of PVY by $M$. persicae (12). There was a positive relationship between virus transmission and titer levels by both A. gossypii and M. persicae (31).

SPFMV was transmitted at a greater rate across all host species for A. gossypii from mixed-infected than single-infected plants. Virus titers did not differ between mixed- and single-infected plants within species except that titers were higher for mixed-infected than single-infected Beauregard and single-infected than mixed-infected I. cordatriloba. Our results suggest that SPFMV titer accumulation in mixed infections may be enhanced, as in the case of Beauregard; reduced, as with I. cordatotriloba; or unaffected, as with $I$. hederacea. However, despite the differences, mixed infections seem to be favorable virus sources compared with single infections, indicating that there could be other contributing factors apart from virus titer. Kokkinos and Clark (20) reported significantly greater titers of SPFMV in sweetpotato plants when co-infected with a Crinivirus sp. SPCSV than in single-infected plants. However, there was no significant difference in SPFMV titer in single and co-infections with two other sweetpotato Po-

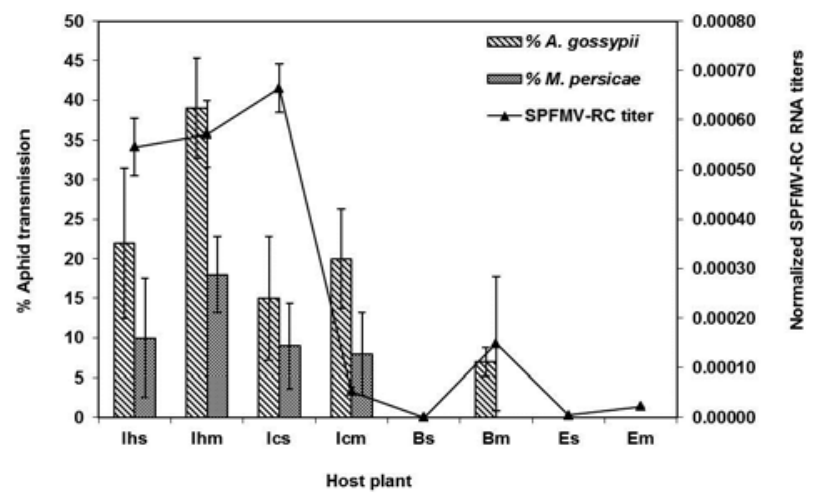

Fig. 1. Relative titers of Sweet potato feathery mottle virus russet crack strain (SPFMV-RC) and frequency of SPFMV transmission by Aphis gossypii and Myzus persicae in singly and mixed infected host plants ( $\mathrm{lh}=$ Ipomoea hederacea, $\mathrm{Ic}=\mathrm{I}$. cordatotriloba, $\mathrm{B}=$ Beauregard sweetpotato, $\mathrm{E}=$ Evangeline sweetpotato, $\mathrm{s}=$ singly infected, $m=$ mixed infected).

Table 2. Sweet potao feathery mottle virusvirus (SPFMV) transmission from Ipomoea spp. from single and mixed infections by Aphis gossypii and Myzus persicae following 3 -s acquisition probes ${ }^{\mathrm{a}}$

\begin{tabular}{lcccc}
\hline & \multicolumn{2}{c}{ Transmission (\%) } \\
\cline { 2 - 5 } & \multicolumn{1}{c}{ A. gossypii } & \multicolumn{2}{c}{ M. persicae } \\
\cline { 2 - 5 } Acquisition source $^{\mathbf{b}}$ & Mean & CI & Mean & CI \\
\hline Ipomoea batatas 'Beauregard' SPFMV-RC & 0 & NT & 0 & NT \\
I. batatas Beauregard mixed & 1 & $0.0-4.7$ & 0 & NT \\
I. cordatotriloba SPFMV-RC & 11 & $6.7-19.5$ & 3 & $0.8-7.8$ \\
I. hederacea SPFMV-RC & 10 & $6.0-18.3$ & 10 & $6.0-18.3$ \\
Control & 0 & NT & 0 & NT \\
\hline
\end{tabular}

${ }^{a}$ Means within a column (acquisition sources) with same confidence interval $(\mathrm{CI})$ range are not significantly different $(P>0.05)$. NT $=$ no transmission occurred; therefore, no CIs can be calculated.

${ }^{\mathrm{b}} \mathrm{RC}=$ russet crack strain; $n=100$ for each acquisition source.

Table 3. Frequency of detection of Sweetpotato feathery mottle virus (SPFMV) and Sweet potato virus G (SPVG) in test plants following Aphis gossypii and Myzus persicae transmission from mixed-infected hosts following a 30 -s acquisition probe ${ }^{\mathrm{a}}$

\begin{tabular}{|c|c|c|c|c|c|c|}
\hline \multirow[b]{2}{*}{ Host } & \multicolumn{3}{|c|}{ A. gossypii } & \multicolumn{3}{|c|}{ M. persicae } \\
\hline & SPFMV & SPVG & SPFMV + SPVG & SPFMV & SPVG & SPFMV + SPVG \\
\hline 'Beauregard' & 4 & 0 & 3 & - & - & - \\
\hline 'Evangeline' & - & - & - & - & - & - \\
\hline Ipomoea cordatotriloba & 16 & 0 & 4 & 8 & 0 & 0 \\
\hline I. hederacea & 36 & 0 & 3 & 18 & 0 & 0 \\
\hline
\end{tabular}

${ }^{\text {a }}$ For each acquisition source, $n=100$; - indicates not tested due to lack of successful transmission. 
tyvirus spp., SPVG and SPV2 (C. D. Kokkinos and C. A. Clark, unpublished data). Therefore, our significant differences between mixed- and single-infected virus titers in Beauregard suggest that there could be other unknown viruses contributing to enhanced titer in sweetpotato apart from the known SPVG and SPV2. Mixed virus infections in other systems are reported to cause severe symptoms and enhanced, reduced, or neutral effect on virus titers in either all or some of the viruses involved (36). Transmission of viruses by aphids from mixed-infected plants differs, probably depending on titer enhancement or suppression by the given virus. For example, Hampton and Sylvester (15) reported increased transmission of Alfalfa mosaic virus (AMV) by the pea aphid Acyrthosiphon pisum when co-infected with Pea streak virus (PSV) compared with single-infected plants. However, they observed the reverse trend with PSV, whose transmission efficiency was lower when co-infecting with AMV than when alone. Our results are contrary to those of Pinto et al. (26), who observed reduced transmission of Zucchini yellow mosaic virus (ZYMV), Cucumber mosaic virus (CMV), and Papaya ring spot virus from mixed infections compared with single-infected plants by both Aphis gossypii and M. persicae. Wintermantel et al. (42) also reported reduced transmission of two Crinivirus spp. when co-infecting compared with single infections. Significant reduction of SPFMV titer in mixed- compared with single-infected I. cordatotriloba could be attributed to host effect on virus titer accumulation pattern. Some viruses may have enhanced or reduced titer in co-infections versus single infections depending on host plant species or cultivar $(36,42)$.

Overall, A. gossypii had a significantly greater transmission efficiency than $M$. persicae. A. gossypii was also able to transmit SPVG in some incidences from the mixed-infected host plants, a trend that was not observed with $M$. persicae, which only transmitted SPFMV. Although our results under laboratory conditions suggest that $A$. gossypii is a more efficient vector of SPFMV, field conditions present a different case, because the importance of a vector is determined based on its propensity, a measure determined by both vector efficiency and abundance (16). Preliminary data on aphids caught in Louisiana sweetpotato fields using yellow sticky and pan traps indicate that $A$. gossypii is more abundant than $M$. persicae. Single or multiple virus species or strains can be transmitted from mixed-infected hosts depending on the aphid species (30). Several publications have reported differences in virus transmission by various aphid species $(17,41)$. These differences in transmission are attributed to interaction of virus particles, helper component protein, surface proteins on the aphid stylet, and virus coat protein that affect virus binding capacity and vector behavior $(25,36)$. The transmission efficiency of SPFMV by $M$. persicae (0 to $18 \%$ ) in our experiments was comparable with what has been reported for some Potyvirus spp.; for example, PVY, 4.7 to $71.1 \%(4,11,28)$; Soybean mosaic virus, $18.6 \%$; AMV, 5 to $19 \%$; and ZYMV, 20 to $60 \%$ ) (37). Transmission by A. gossypii was comparable with what has been reported on other Potyvirus spp. (for example, ZYMV, 27.5\%; 43). Successful transmission of SPFMV by $M$. persicae and $A$. gossypii in as few as 3 s reveals how easily this virus can be acquired and spread in the fields by these aphid species. Earlier studies by McLean (23) revealed a similar trend.

Our findings demonstrate that transmission of SPFMV depends on host plant, aphid species, and infection status. The knowledge of transmission of SPFMV from Ipomoea hosts by the two aphid species $M$. persicae and A. gossypii is essential to accurately estimate transmission risks with regard to aphid species composition in sweetpotato fields. Further studies are needed to fully assess the role of morning glory species in epidemiology of sweetpotato Potyvirus spp. Although SPFMV transmission from morning glory plants appeared greater than from sweetpotato, in the field, sweetpotato is planted from vegetative cuttings, many of which are already infected, whereas the morning glory plants germinate from true seed that are not initially infected. Preliminary observations indicate that the morning glory plants get infected during the months of June to July when SPFMV is already spreading among sweetpotato plants (E. N. Wosula, unpublished). This suggests that the morning glory seedlings are not sources of primary inoculum. However, prevalence of I. hederacea and I. cordatotriloba in sweetpotato-growing regions may serve as elevated secondary sources of SPFMV and, hence, may play a role in SPFMV epidemiology. Differences in accumulation of SPFMV titers in mixed- and single-infected plants, depending on host, may play a role in adaptation and evolution of the virus and impact virus epidemiology. Regular trapping and identification of aphid species in sweetpotato fields could be essential in monitoring proportions of vector species and their impact on virus spread.

Recognition of the relative transmission efficiency of different vector species and suitability of different potential hosts for virus acquisition provides critical information for understanding the epidemiology and developing approaches to limit spread of SPFMV. Preliminary results of a field study suggest that virus titers may vary dramatically under field conditions and may differ from greenhouse conditions (E. N. Wosula, unpublished). The fact that SPFMV was acquired quickly and transmitted in a nonpersistent manner also suggests that mineral or stylet oils, which have been reported to minimize virus spread of nonpersistent aphid-borne viruses (32), should be evaluated for their potential to inhibit transmission of SPFMV, as another step toward devising integrated strategies to minimize virus spread. Further work is required to determine whether lack of transmission from Evangeline sweetpotato is due to resistance to SPFMV or effect on the behavior of the vector. Preliminary studies reveal that $M$. persicae has a lower intrinsic rate of increase on Evangeline compared with Beauregard, and SPFMV titers are lower in Evangeline compared with Beauregard in field samples (E. N. Wosula, unpublished).

\section{Acknowledgments}

This project was supported by funds provided through the United States Department of Agriculture Specialty Crop Research Initiative project number CSREES 2009-51181-06071 and the Louisiana Sweet Potato Commission.

\section{Literature Cited}

1. Alvarez, J. M., and Srinivasan, R., and. 2005. Evaluation of hairy nightshade as an inoculum source for aphid-mediated transmission of Potato leaf roll virus. J. Econ. Entomol. 98:1101-1108.

2. Biggerstaff, B. J. 2006. PooledInfRate, Version 3.0: A Microsoft Excel AddIn to Compute Prevalence Estimates from Pooled Samples. Centers for Disease Control and Prevention, Fort Collins, CO.

3. Byamukama, E., Gibson, R. W., Aritua, V., and Adipala, E. 2004. Withincrop spread of sweet potato virus disease and the population dynamics of its whitefly and aphid vectors. Crop Prot. 23:109-116.

4. Cervantes, F. A., and Alvarez, J. M. 2011. Within plant distribution of Potato virus $Y$ in hairy nightshade (Solanum sarrachoides): an inoculum source affecting PVY aphid transmission. Virus Res. 159:194-200.

5. Clark, C. A., Davis, J. A., Abad, J. A., Cuellar, W. J., Fuentes, S., Kreuze, J. F., Gibson, R. W., Mukasa, S. B., Tugume, A. K., Tairo, F., and Valkonen, J. P. T. 2012. Sweetpotato viruses: 15 years of progress on understanding and managing complex diseases. Plant Dis. 96:168-185.

6. Clark, C. A., Derrick, K. S., Pace, C. S., and Watson, B. 1986. Survey of wild Ipomoea spp. as potential reservoirs of Sweet potato feathery mottle virus in Louisiana. Plant Dis. 70:931-932.

7. Clark, C. A., and Hoy, M. W. 2006. Effects of common viruses on yield and quality of Beauregard sweetpotato in Louisiana. Plant Dis. 90:83-88.

8. Clark, C. A., Hoy, M. W., Valverde, R. A., La Bonte, D. R., and Cannon, J. M. 2002. Effects of viruses on sweetpotatoes in Louisiana, USA. Pages 238-241 in: Potential of Root Crops for Food and Industrial Resources, Twelfth Symp. Int. Soc. Trop. Root Crops. M. Nakatani and K. Komaki, eds. Tsukuba, Japan.

9. Clark, C. A., and Moyer, J. W. 1988. Compendium of Sweet Potato Diseases. American Phytopathological Society, St. Paul, MN.

10. Clark, C. A., Smith, T. P., Ferrin, D. M., and Villordon, A. Q. 2010. Performance of sweetpotato foundation seed after incorporation into commercial operations in Louisiana. HortTechnology 20:977-982.

11. Davis, J. A., Radcliffe, E. B., and Ragsdale, D. W. 2005. Soybean aphid, Aphis glycines Matsumura, a new vector of Potato virus $Y$ in potato. Am. J. Potato Res. 82:197-201.

12. De Bokx, J. A., Vanhoof, H. A., and Piron, P. G. M. 1978. Relation between concentration of Potato-virus $Y N$ and its availability to Myzus persicae. Neth. J. Plant Pathol. 84:95-100.

13. Food and Agricultural Organization. 2005. Food and Agricultural Organization Statistics. Food and Agricultural Organization of the United Nations, Rome. 
14. Gutiérrez, D. L., Fuentes, S., and Salazar, L. F. 2003. Sweetpotato virus disease (SPVD): distribution, incidence, and effect on sweetpotato yield in Peru. Plant Dis. 87:297-302.

15. Hampton, R. O., and Sylvester, E. S. 1969. Simultaneous transmission of 2 pea viruses by Acyrthosiphon pisum quantified on sweetpea as diagnostic local lesions. Phytopathology 59:1663-1667.

16. Irwin, M. E., and Ruesink, W. G. 1986. Vector intensity: a product of propensity and activity. Pages 13-33 in: Plant Virus Epidemics: Monitoring, Modelling and Predicting Outbreaks. G. D. McLean, R. G. Garrett, and W. G. Ruesink, eds. Academic Press, Sydney, Australia.

17. Kennedy, G. G., and Moyer, J. W. 1982. Aphid (Homoptera, Aphididae) transmission and separation of 2 strains of Sweet-potato feathery mottle virus from sweet-potato. J. Econ. Entomol. 75:130-133.

18. Kennedy, J. S., Day, M. F., and Eastop, V. F. 1962. A Conspectus of Aphids as Vectors of Plant Viruses. Commonwealth Institute of Entomology, London.

19. Kokkinos, C. D., and Clark, C. A. 2006. Real-time PCR assays for detection and quantification of sweetpotato viruses. Plant Dis. 90:783-788.

20. Kokkinos, C. D., and Clark, C. A. 2006. Interactions among Sweet potato chlorotic stunt virus and different potyviruses and potyvirus strains infecting sweetpotato in the United States. Plant Dis. 90:1347-1352.

21. Kreuze, J. F., Karyeija, R. F., Gibson, R. W., and Valkonen, J. P. T. 2000. Comparisons of coat protein gene sequences show that East African isolates of Sweet potato feathery mottle virus form a genetically distinct group. Arch. Virol. 145:567-574.

22. Loebenstein, G., Thottappilly, S., Fuentes, S., and Cohen, J. 2009. Virus and Phytoplasma diseases. Pages 105-134 in: The Sweetpotato. G. Loebenstein and S. Thottappilly, eds. Springer Science + Business Media BV 2009.

23. McLean, D. D. 1959. Some aphid vector-plant virus relationships of the feathery mottle virus of sweet potato. J. Econ. Entomol. 52:1057-1062.

24. Moyer, J. W., and Salazar, L. F. 1989. Viruses and viruslike diseases of sweet-potato. Plant Dis. 73:451-455.

25. Ng, J. C. K., and Falk, B. W. 2006. Virus-vector interactions mediating nonpersistent and semipersistent transmission of plant viruses. Annu. Rev. Phytopathol. 44:183-212.

26. Pinto, Z. V., Rezende. J. A. M., Yuki. V. A., and Piedade, S. M. S. 2008. Ability of Aphis gossypii and Myzus persicae to transmit Cucumber mosaic virus in single and mixed infection with two potyviruses to zucchini squash. Summa Phytopathol. 34:183-185.

27. Powell, G., Tosh, C. R., and Hardie, J. 2006. Host plant selection by aphids: behavioral, evolutionary, and applied perspectives. Annu. Rev. Entomol. 51:309-330.

28. Ragsdale, D. W., Radcliffe, E. B., and DiFonzo, C. D. 2001. Epidemiology and field control of PVY and PLRV. Pages 237-270 in: Virus and Virus-like Diseases of Potatoes and Production of Seed-Potatoes. G Loebenstein, P. H. Berger, A. A. Brunt, and R. H. Lawson, eds. Kluwer Academic Publishers, Dordrecht, The Netherlands.

29. Rannali, M., Czekaj, V., Jones, R. A. C., Fletcher, J. D., Davis, R. I., Mu, L., and Valkonen, J. P. T. 2009. Molecular characterization of Sweet potato feathery mottle virus (SPFMV) isolates from Easter Island, French Polynesia, New Zealand, and Southern Africa. Plant Dis. 93:933-939.

30. Rochow, W. F. 1972. Role of mixed infections in transmission of plant viruses by aphids. Annu. Rev. Phytopathol. 10:101-124.

31. Romanow, L. R., Moyer, J. W., and Kennedy, G. G. 1986. Alteration of efficiencies of acquisition and inoculation of Watermelon mosaic virus- 2 by plant-resistance to the virus and to an aphid vector. Phytopathology 76:1276-1281.

32. Simons, J. N., and Zitter, T. A. 1980. Use of oils to control aphid-borne viruses. Plant Dis. 64:542-546.

33. Souto, E. R., Sim, J., Chen, J., Valverde, R. A., and Clark, C. A. 2003. Properties of strains of Sweet potato feathery mottle virus and two newly recognized potyviruses infecting sweet potato in the United States. Plant Dis. 87:1226-1232.

34. Srinivasan, R., and Alvarez, J. M. 2008. Effect of mixed viral infections (Potato virus Y-Potato leafroll virus) on biology and preferences of vectors Myzus persicae and Macrosiphum euphorbiae (Hemiptera: Aphididae). J. Econ. Entomol. 100:646-655.

35. Stubbs, L. L., and McLean, D. L. 1958. A note on aphid transmission of a feathery mottle virus of sweet potato. Plant Dis. Rep. 42:216.

36. Syller, J. 2011. Facilitative and antagonistic interactions between plant viruses in mixed infections. Mol. Plant Pathol. Online publication. doi:10.1111/J.1364-3703.2011.00734.X

37. Symmes, E. J., and Perring, T. M. 2007. Intraspecific variation in Zucchini yellow mosaic virus transmission by Myzus persicae and the impact of aphid host plant. J. Econ. Entomol. 100:1764-1772.

38. Tugume, A. K., Mukasa, S. B., and Valkonen, J. P. T. 2008. Natural wild hosts of Sweet potato feathery mottle virus show spatial differences in virus incidence and virus-like diseases in Uganda. Phytopathology 98:640-652.

39. Untiveros, M., Quispe, D., and Kreuze, J. 2010. Analysis of complete genomic sequences of isolates of the Sweet potato feathery mottle virus strains $\mathrm{C}$ and EA: molecular evidence for two distinct potyvirus species and two P1 protein domains. Arch. Virol. 155:2059-2063.

40. Valverde, R. A., Lozano, G., Navas-Castillo, J., Ramos, A., and Valdes, F. 2004. First report of Sweet potato chlorotic stunt virus and Sweet potato feathery mottle virus infecting sweet potato in Spain. Plant Dis. 88:428-428.

41. Verbeek, M., Piron, P. G. M., Dullemans, A. M., Cuperus, C., and van der Vlugt, R. A. A. 2010. Determination of aphid transmission efficiencies for N, NTN and Wilga strains of Potato virus Y. Ann. Appl. Biol. 156:39-49.

42. Wintermantel, W. M., Cortez, A. A., Anchieta, A. G., Gulati-Sakhuja, A., and Hladky, L. L. 2008. Co-infection by two criniviruses alters accumulation of each virus in a host-specific manner and influences efficiency of virus transmission. Phytopathology 98:1340-1345.

43. Yuan, C., and Ullman, D. E. 1996. Comparison of efficiency and propensity as measures of vector importance in zucchini yellow mosaic potyvirus transmission by Aphis gossypii and A. craccivora. Phytopathology 86:698703. 